\title{
How to Cultivate Students' Innovation Ability in Wushu Teaching in Sport Colleges and Universities
}

\author{
Rui Peng \\ Yichun University, Yichun, Jiangxi, China
}

\begin{abstract}
Wushu as Chinese national traditional sports is cultural treasure. Occupies an important position in the national fitness program has a strong foundation for the masses. But the university is an important site for the promotion, development, popularization. But Wushu teaching in knowledge, skills as the main task, not to cultivate students' innovation ability to improve the education development level, this paper will explore how to cultivate students' innovation ability in Wushu teaching.
\end{abstract}

KEYWORD: Wushu teaching; Cultivate; Innovation ability

\section{INTRODUCTION}

Wushu is China's national cultural heritage, is China national traditional sports has a long history, it is the ancient working people in the social labor is summed up ceaselessly and develop, and gradually formed a complete system of Wushu. "Innovation is the soul of a nation's progress, is the national power" prosperity must strengthen national innovation ability to national survival level. Education in training the national creative ability and spirit is shouldering the important mission. The formation and development of Wushu system is also verified by the innovation of a thing and development play a role. Therefore in the Wushu teaching in the new era how to cultivate the students' innovation ability research, aiming to make the comprehensive quality of Wushu this national traditional sports better development and better improve the students and inspire students' innovation consciousness.

\section{ANALYSIS OF THE CURRENT SITUATION OF COLLEGE SPORTS PROFESSIONAL WUSHU TEACHING}

Wushu as Chinese national traditional sports, fitness, entertainment, self-defense self-cultivation and the function of preventing and curing diseases. Occupies an important position in the national fitness program, data statistics about 60000000 of practitioners. The main function of school is the transmission of human knowledge; education is an important place for people. Wushu as a representative of the national traditional sports culture, the inheritance and development of it must not underestimate the special heritage sites and positions of human knowledge, can not easily give up school physical education. So the school is an important place for the development of Wushu, popularization.

Analyses the present situation of the teaching: teaching content is different, the lack of theoretical teaching, from the survey data to understand, the university Wushu teaching material content is different, there is imbalance, the material is different and even the lack of theoretical knowledge, resulting in the cavity, affecting teaching quality. The teaching content is narrow, lack of attractiveness. Usually in Changquan, Nanquan, primary sword and Tai Chi Sword for the teaching project, while the traditional health care, guidance works made few. The teaching method is relatively old, lack of scientific method. The teaching method is relatively old, lack of scientific method. Still follow the traditional theories and methods for thousands of years, only pay attention to "teach" "learning" as the traditional form of teaching and implementation of teaching, is not sufficient to modern technology used in Wushu teaching, teaching methods single, aging, single rigid way student activities, make students lack the initiative to actively explore, lack of intelligence training closely related with motor skills, can only accept the guidance, and can not take the initiative to cope with change, once the habit is blocked, emotion, attitude will be affected, but not control, can not play a normal level of skill. An important factor in the teaching conditions such as space, equipment, funds also restrict the Wushu teaching.

So the College Wushu teaching still to form the 
knowledge, skills and skills as the main task of development, ignoring the cultivation of students' innovation ability and non intellectual factors, more is not to train and improve students' innovative consciousness and innovative ability of modern society and education development level, the lack of measures and measures to improve the students' innovation consciousness and innovation ability.

\section{TO IMPROVE THE COMPREHENSIVE ABILITY OF THE STUDENTS ROLE IN CULTIVATING INNOVATION ABILITY}

Innovation is the soul of a nation's development, college students are the reserve force of national development, the cultivation of students' innovative ability of the country's future and development, educators or educational departments should think more about how to improve the innovation ability of students, so as to improve the students' comprehensive quality. Pay attention to the training of students' creative ability in Wushu teaching can improve the comprehensive quality.

\subsection{To improve the practice ability}

The creative inspiration from the majority of real life, real life is the best material for innovation, actively participates in social practice, theory with practice, learn in order to practice. Therefore, to participate in the social practice of college students to cultivate the innovation ability of the role should not be underestimated, especially should take part in some activity of innovation of science and technology, social practice actively can enhance students sense of innovation.

\subsection{To enhance the sense of competition}

Competition is the main feature of twenty-first Century, to survive in the fierce competition and development must attract others where there is innovation, only innovation can always walk in front of others, can stand, can develop, so the cultivation of innovation ability in a certain angle can improve the students' sense of competition.

\subsection{To improve the ability to analyze and solve the problems}

In the process of innovation, to break the normal procedure, it will face difficulties and many problems, so it requires students to analyze problems, and to think about how to solve the problem, only by constantly discover problems, analyze problems, to solve the problem, in order to achieve innovation. Therefore, the cultivation of innovative ability can improve the ability to analyze and solve the problems.

\section{HOW TO CULTIVATE AND IMPROVE STUDENTS' INNOVATION ABILITY}

The materialist dialectics tells us that things are changing with the development, traditional Wushu education pays attention to the achievements of civilization heritage of human creation, rather than the process of creation, people enjoy the results of previous through education, education is the passive receivers of knowledge, rather than active exploration, education and creative barely coherent, innovation is the soul of any things only innovation development. So is the Wushu teaching, only pay attention to the cultivation of students' innovation ability to make Wushu continuous and healthy development.

\subsection{Paying attention to basic skills teaching}

Improve the students' innovation ability should start from the foundation, any knowledge or skills must have a good foundation, focus on the basic skills of Wushu teaching, only in the basis to innovation and development of football players, for example, if not a good stop, pass, shoot the basic functions, the coach you cannot perform his tactical system, the team will not play the cooperation and good. Wushu is the same, if even the bow, horses, servants step is done badly, where beauty and as talk not to mention innovation. Only with the solid basic skills, learning Wushu can be better, can we talk about the innovation in this foundation. Of course the Wushu basic training is very boring, many students of the professional sports have interviewed almost all the students has such a view. Then we can do some innovation as in practice basic skills: let the students take turns to do preparatory activities not only improve the students' ability of organization can improve the teaching ability. Anyway, take various measures is not boring and learning principles.

\subsection{Question teaching method}

"The problem is the source of innovation, doubt is the mother of invention" "suspect" and "Q" is a creative, problem teaching method is defined by the teacher or students to ask questions, through selfstudy, independent analysis of issues, to explore the interaction problem, and the test of practice, and then solve a teaching method problem. These inspiring and encouraging students to ask questions, dare to explore, dare to express different views, and then guide the students to gradually research, discussion, in order to activate the student's awareness of innovation, especially for some different points of view, require students to further explore the key and essence. Analysis of the problem from a different angle, guide the students to fully understand the ways and methods, to cultivate students' innovation consciousness. 


\subsection{The self-learning method}

The self-learning method refers to the students in the learning activities, continue to inspire stand on one's own consciousness, play a way of learning initiative and creative, independent study to complete their homework, then the action or routine teaching myself to teach the other students, advocate and the way the new teaching method, which can not only improve the students' self-study ability and teaching ability, but also to train students' innovation consciousness in teaching and learning.

\subsection{Diversified teaching means}

Teaching methods means that the teaching method of teachers teaching, traditional teaching method is "teacher" to "learning" with the development of science and technology of Wushu teaching should use high-tech, such as multimedia teaching now in various disciplines have played a very important role. In the Wushu teaching also can use multimedia, so that students can use multimedia more intuitive, image, vivid learning, so as to improve the students' interest in learning, only have the interest to study and innovation. Also through teaching competition, is also a good teaching method, is to allow students to learn the game modes are compared, to produce competition between students, competition is a way to improve the innovation ability, in addition to other students can do Wushu referee fight each other, it can cultivate students' organization competition ability and improve students' ability of Wushu referee. Take a variety of teaching methods; do not stick in the mud, but also an important way to improve the students' innovation consciousness and ability.

\subsection{The practice teaching process}

Practice is the sole criterion for testing truth, real knowledge comes from practice, teaching method, teaching practice is to let the students from textbooks into practice experience and test knowledge. For example, the students are preparing with the class, not only can exercise and improve the education level of students, but also can improve the comprehensive quality. The cultivation of students' creative ability in training and have a significant role in improving the innovation ability of students: creating the preparatory activities, creating routines, creating training combined movements, creating Wushu programs, so that the students can make full use of the existing knowledge and imagination, the cultivation of students' creative ability is helpful to improve the students' divergent thinking, divergent thinking is based on the existing information, thinking from different angles and in different directions, to cultivate the students ability to infer other things from one fact, seek ways and means to solve the problem from various aspects, so as to improve their innovative consciousness and innovative ability.

\subsection{Expand the teacher's demonstration effect}

Expand the teacher's demonstration influence is that teachers focus on the use of teaching methods and means of innovation of teaching, use your own words and deeds influence character by environment effects and develop students awareness of innovation, stimulate the students' innovation spirit, innovation. Teachers are often students mind example, novel and unique teaching methods can enlarge the teacher demonstration influence, enhance the attraction for students learning.

\section{CONCLUSION}

Teaching education professional Wushu sports is an important way to cultivate the Wushu teachers, teachers should constantly improve the comprehensive quality of students in the process of cultivation, lay the foundation for the development of wushu. Improve the overall quality of students is to improve students' consciousness and ability of innovation, only innovation can make Wushu development of good health. The cultivation of innovative ability in the teaching method and the way is to constantly update, to cater to students' psychological teach students in accordance with their aptitude, pay attention to students' interest and enthusiasm fully combined, can the students' autonomous learning of independent innovation. At the same time, teachers must strive to become an innovative people. Because Wushu teachers as leader of Wushu in the process of teaching, is the main participants and practitioners of innovation education. A too observant of conventional standards. Teacher is unlikely to go beyond the traditional, to the creation of training students' innovation consciousness and ability of teaching mode. Therefore, teachers must learn and accept new ideas of education, exploring teaching method to develop students' innovation ability.

\section{REFERENCES}

[1] Zhang, M.Q. 2002. On the Relationship between Wushu Teaching and Students' Creation. Journal of Hebei Institute of Physical Education 16(2): 68-69.

[2] Hao, S.R. 2002. On the Study of Improving Students' Practical Competence in Wushu Majoring in Normal Universities. Journal of Hebei Institute of Physical Education 16(2): 74-75.

[3] Li, Q.Y. 2004. An Experimental Research on Students' Comprehensive and Creative Ability in Wushu Teaching. Journal of Chenzhou Teachers College 25(5): 102-104. 